\title{
SUPERVISI KEPALA SEKOLAH UNTUK MENINGKATKAN KINERJA TENAGA PENDIDIK
}

\author{
Bashirotul Hidayah \\ Institut Agama Islam Bani Fattah Jombang, Indonesia \\ bashirotulhidayah@gmail.com
}

\begin{abstract}
Educational institutions as a forum for the intellectual life of the nation are required to make various efforts and innovations in order to improve the quality of education. As an institution, of course, schools must have learning tools and educators to carry out the learning process. In addition, schools must also have good and efficient institutional and employee governance. This is where the role of the principal is tested and required to be able to regulate and manage the school institution as well as all educators and academicians within the scope of the school so that they can progress and be organized as the vision and mission of the institution and to improve the quality of the school in a comprehensive and sustainable manner.
\end{abstract}

Keyword: Performance Improvement, Education Staff, Supervision Head Of School

\section{Pendahuluan}

Pendidikan merupakan salah satu bagian yang terpenting dalam kehidupan masyarakat karena pendidikan merupakan bekal kehidupan manusia untuk menyambut masa depanya,dengan pendidkan manusia akan dapat hidup sesuai dengan norma-norma dan nilai-nilai kemanusian, 
akan tetapi pebelajaran dalam pendidikan memerlukan adanaya lembaga atau organisai pendidikan yang mana focus dalam mengurus kependidikan,oleh karena dalam lembaga pendidikan pasti memerlukan manajemen atau kepala sekolah sebgai pengedali dalam berjalanya kependidikan dalam lembaga tersebit serta tenaga pendidik yang sering disebut dengan guru,yang mana tugasnya secara profesional adalah untuk mencerdaskan masyarakat bangsa. ${ }^{1}$

Menurut UU No.20 tahun 2003 tentang Sistem Pendidikan Nasional bahwa pendidikan adalah usaha sadar dan terencana untuk mewujudkan suasana belajar dan proses pembelajaran agar peserta didik secara aktif mengembangkan potensi dirinya untuk memiliki kekuatan spiritual keagamaan, pengendalian diri, kepribadian, kecerdasan, akhlak mulia, serta ketrampilan yang diperlukan dirinya, masyarakat, Bangsa dan Negara. Dalam pelaksanaan fungsi dan tugasnya, guru sebagai profesi menyandang persyaratan tertentu sebagaimana tertuang di dalam Undang-Undang Republik Indonesia Nomor 20 tahun 2003 tentang Sistem Pendidikan Nasional. Dalam pasal 39 (1) dan (2) dinyatakan bahwa: Tenaga kependidikan bertugas melaksanakan administrasi, pengelolaan, pengembangan, pengawasan, dan pelayanan teknis untuk menunjang proses pendidikan pada satuan pendidikan. Pendidik merupakan tenaga profesional yang bertugas merencanakan dan melaksanakan proses pembelajaran, menilai hasil pembelajaran, melakukan pembimbingan dan pelatihan, serta melakukan penelitian dan pengabdian kepada masyarakat, terutama bagi pendidik pada perguruan tinggi. ${ }^{2}$

Keberhasilan suatu lembaga pendidikan terletak pada kepemimpinan kepala sekolah. Karena ia merupakan pemimpin dilembaganya, maka ia harus mampu membawa lembagnya kearah tercapainya tujuan yang telah ditetapkan, ia harus mampu melihat adanya perubahan serta mampu melihat masa depan dalam kehidupan global yang lebih baik. Kepala sekolah harus bertanggung jawab atas pelancara dan keberhasilan semua urusan pengaturan dan pengelolaan sekolah secara formal kepada atasanya atau secara informal kepada masyarakat yang telah menitipkan anak didiknya. Kepala sekolah sebagai seorang pendidik, administrator, pemimpin, dan supervisor, diharapkan dengan sendirinya dapat mengelolah lembaga pendidikan kearah perkembangan yang lebih baik dan dapat menjanjikan masa depan. ${ }^{3}$

\footnotetext{
${ }^{1}$ Marno, Manajemen dan Kepemimpinan Pneidikan Islam (bandung: PT. Rafika, Aditama, 2013), 31

${ }^{2}$ Ibid. 31

${ }^{3}$ Ibid, 33
} 
Dinegara maju kapala sekolah mendapat sebutan bermacammacam. Ada yang menyebut Guru kepala (Head teacher atau head master), kepala sekolah (Principa), Kepala sekolah yang mengajar (Teaching Principal), kepala sekolah pensupervisi (Supervising principal), direktur (director), administrator (Aministrator), pemimpin pendidikan (adicational leaderrship). Penyebutan yang berbeda ini menurut Mantja disebabkan adanya kereteria yang tersyaratkan kompetensi professional kepala sekolah. Sebagai administrator, kepala sekolah harus mampu mendayagunakan sumber yagn bersedia secara optimal. Sebagian menejer, kepala sekolah harus mampu bekerja sama dengan orang lain dalam berorganisasi sekolah. Sebagai pemimpin pendidikan, kepala sekolah harus mampu mengkoordinasi dan menggerakkan potensi manusia untuk mewujudkan tujuan pendudukan itu sebagai supervisor, Kepala sekolah harus mampu membantu guru meningkatkan kapasitasnya untuk membelajarkan murid secara optimal. ${ }^{4}$

Kepala sekolah merupakan jabatan karir yang diperoleh seseorang setelah sekian lama menjabat sebagai guru. Seseorang diangkat dan diporcaya menduduki jabatan kepala sekolah harus memenuhi kriteriakriteria yang disyaratkan yang dimaksud. Davis, G.A dan Thomas, M.A. (1989) berpendapat bahwa kepala sekolah yang efektif mempunyai karakrteristik sebagai berikut :

1. Mempunyai jiwa kepemimpinan dan mampu memimpin sekolah

2. Memiliki kemampuan untuk memecahkan masalah

3. Memiliki ketrampilan social

4. Professional dan kompeten dalam bidang tugasnya

Menurut Siagian,SP.,1986 Pemimpin organisasi terutama dalam bidang pendidikan setidaknya memiliki ciri-ciri dan kemampuan sebagai berikut :

1. Mampu mengambil keputusan

2. Mempunyai kemampuan hubungan manusia

3. Mempunyai keahlian dalam berkomunikasi

4. Mampu memberikan motivasi kerja kepada bawahanya.

De Roche, E.F (1985) berpendapat bahwa kepala sekolah (principal) sebagai pemimpin dan administrator harus mempunyai kemampuan :

1. Mempunyai sifat-sifat kepemimpinan

2. Mempunyai harapan tinggi (bigh expectation) terhadap sekolah

3. Mampu memberdayakan sumberdaya sekolah

4. Professional dalam bidangnya. ${ }^{5}$

\footnotetext{
${ }^{4}$ Ibid, 33

${ }^{5}$ Wahyudi, Kepemimpina Kepala Sekolah Dalam Organisasi embelajaran (Bandung, Al Fabeta, 2012), 64
} 
Jabatan kepala sekolah memerlukan orang-orang yang mampu memimpin sekolah dan professional dalam bidang kependidikan. Namun kenyataanya di lapangan membuktikan bahwa tidak semua kepala sekolah memenuhi kriteria yang ditentukan tetapi lebih mengutamakan pada golongan atau kepangkatan yang dijalani melalui masa kerja.

Peran kepala sekolah sebagai administrator,sebagai manajer dan sebagai supervisor pendidikan perlu dilengkapi dengan keterampilan manajerial. Terdapat tiga bidang keterampilan manajerial yang perlu dikuasai oleh manajer pendidikan dengan mengacu pada pendapat Robert Katz yaitu keterampilan konseptual (conceptual skill), keterampilan hubungan manusia (buman skill), ketrampilan teknik (technical skill). Ketiga keterampilan manjerial tersebut diperlukan untuk melaksanakan tugas manajerial secara efektif meskipun penerapan masing-masing keterampilan tersebut tergantung pada tingkat manajer dalam organisasi. ${ }^{6}$

Perangkat sekolah seperti kepala sekolah, dewan guru, siswa, pegawai atau karyawan harus saling mendukung untuk bekerja sama mencapai tujuan yang telah ditetapkan. Oleh karena itu dapat dikatakan bahwa sukses atau tidaknya suatu organisasi dalam mencapai tujuan yang telah ditentukan sangat tergantung atas kemampuan pemimpinnya untuk menumbuhkan iklim kerja sama agar dengan mudah dapat menggerakkan sumber daya manusia yang ada, sehingga pendayagunaannya dapat berjalan secara efektif dan efisien. ${ }^{7}$

Kepala sekolah memiliki peranan yang strategis untuk meningkatkan mutu pendidikan suatu sekolah. Kepala sekolah tidak saja berperan sebagai pemimpin pembelajaran, tetapi lebih dari itu kepala sekolah merupakan pemimpin dari semua fungsi-fungsi kepemimpinan dalam suatu sekolah seperti perencanaan, pembinaan karir, koordinasi dan evaluasi. Kepala sekolah sebagai seorang supervisor yang bijaksana harus mampu membuat rencana tentang apa yang akan dilakukan sebagai alternatif pemecahan permasalahan yang terjadi dikalangan guru yang dipimpinnya dengan saling bekerja sama dalam menyesuaikan rencana dan situasi baru yang timbul. ${ }^{8}$

Dalam melaksanakan kegiatan atau pekerjaan-pekerjaan dalam lembaga, maka perlu dilakukan penilaian atas pekerjaan yang telah dilaksanakan oleh para karyawan atau guru. Penilaian prestasi kerja merupakan salah satu proses yang dilakukan instansi pemerintah atau perusahaan dalam mengevaluasi kemampuan kinerja guru. Penilaian ini dimaksud untuk melihat sejauh mana perkembangan kualitas pegawai

\footnotetext{
${ }^{6}$ Ibid, 65

7 Ibid, 66

${ }^{8}$ Ibid, 91
} 
atau guru, hasil penilaian prestasi kerja guru dapat diketahui kelebihan dan kekurangan dari pekerjaan yang dinilai serta dapat memberikan umpan balik kepada karyawan yang bersangkutan. Untuk itu semua, tentunya dibutuhkan sistem penilaian prestasi kerja yang jelas dan objektif yang dapat digunakan sebagai pedoman dalam menilai kinerja guru secara adil. Karena penilaian terhadap guru secara objektif dan adil akan mendorong produktivitas yang lebih baik sebagai kekuatan untuk menghasilkan kinerja yang lebih baik.

Karena penilaian kerja karyawan atau dalam hal ini merupakan guru sangatlah penting sebagai tolak ukur seberapa seorang guru melaksanakan pekerjaanya sesuai dengan tugas yang semestinya yang harus dia lakukan. Ketika adanya penilaian maka para guru atau tenaga pendidik akan mengetahui apa sajakah yang menjadikan kelemahan guru dalam melaksanakan kinerjanya. Karena seorang guru merupakan pendidik yang memang bertugas secara proposional sebagai bidangnya. Apabila guru memiliki kuwajiban untuk memberikan pelajaran pada para peserta didik maka itu yang harus dilakukan seorang guru, begitu juga perangkat-perangkat yang terkait dalam melaksanakan pembelajaran atau perangkat-perangkat yang mendukung agar tercapainya pembelajaran yang efektif, seperti halnya membauat RPP, penataan kelas, pengevaluasi, dan banyak lagi yang lainya. Disinilah peran seorang kepala sekolah sangat diperlukan sebagai pendukung atau pendorong dalam mewujudkan pembelajaran dan pendidikan yang efektif dan efesien, kepala sekolah atau atasan mempunyai wewenang untuk mengatur serta menilai para guru atau bawahanya terkait dengan pekerjaan yang dilakukan oleh bawahanya. Dan begitu pula para guru harus dapat bekerja sama dengan tenaga pendidik yang lain seperti kepala sekolah, sehingga ketika ada sesuatu yang belum diketahui bisa mencari informasi langsung dari atasan, guru harus mampu menjalankan tugas mulianya sebgai pendidik tidak boleh keluar dari bidangnya, kedudukan kepala sekolah ini merupakan pokok terpenting dalam setiap lembaga pendidikan maupun organisasi pendidikan, karena setiap sesuatu membutuhkan pangkal atau rujukan dalam mengambil keputusan, apalagi dengan adanya kebijakan pendidikan yang selama ini selalu berubah sehingga para pendidik atau karyawan membutuhkan perhatian atau pengawasan yang lebih ketat dalam mencapai terwujudnya keberhasilan pembelajaran, apalagi diera yang seperti ini guru atau tenaga kependidikan dituntut untuk sesuai tuntutan kebijakan yang telah dibuat, dalam realitanya terkadang banya tenaga pendidik yang tidak sesuai dengan ketentuan kebijakan dari pemerintah, dari sinilah kepala sekolah

${ }^{9}$ Ibid, 8 
peranya merupakan peran sangat penting untuk membantu para bawahanya dalam mewujudkan pembelajaran yang efektif dan efesien. ${ }^{10}$

\section{Pengertian supervise kepala sekolah}

Istilah "supervise" diambil dari perkataan inggris "super-vision" artinya pengawasan. ${ }^{11}$ Supervise pendidikan berarti pengawasan dibidang pendidikan. Orang yang melakukan supervise disebut "supwrvisor" atau pengawas. Istilah supervise dapat pula dijelaskan menurut bentuk perkataanya. Supervise terdiri dari dua kata yakni "super" + "visi". Super artinya : atas atau lebih, visi artinya : lihat,titik atau awasi. Seorang supervisor memang mempunyai posisi diatas atau mempunyai kedudukan yang lebih tinggi dari pada orang-orang yang disupervisinya yang tugasnya adalah melihat,menilik,atau mengawasi orang-orang yang disupervisinya itu. ${ }^{12}$

Hakekat supervise adalah : suatu proses pembimbingan dari pihak atasan kepada guru-guru dan para personalia sekolah lainya yang langsung mengenai belajar para siswa, untuk memperbaiki situasi belajar mengajar, agar para siswa dapat belajar secara efektif dengan prestasi belajar yang semakin meningkat. Sedangkan yang melakukan supervise adalah supervisor. Istilah bimbingan mengacu pada usaha yang bersifat manusiawi yang tidak bersifat otoriter. Yang dimaksud dengan pihak atasan disamping dalam arti hirarki, juga dalam arti kuwenangan atau kompetensi dalam bidang yang disupervisi. Memperbaiki situasi bekerja dan beljar secara efektif terkandung dalam makna bekerja dan belajar secara disiplin, bertanggung jawab, dan memenuhi akuntabilitas. ${ }^{13}$

Dalam hal ini kepala sekolah merupakan supervisor yang mana menjadi atasan bagi karyawanya (dalam hal ini adalah guru atau tenaga pendidikan), kepala sekolah sangatlah bertanggung jawab penuh dalam kelncaran pengelolaan lembaga pendiikan yang diampunya serta berlangsungnya pekerjaan serta belajar yang efektif dan efesien, untuk mewujudkan itu maka kepala sekolah harus memberikan arahan dan melakukan bimbingan kepada bawahanya. Dalam lembaga pendidikan masing-masing kepala sekolah merupakan pangkat atau jabatan tertinggi dalam memegang kekuasaan berjalanya lembaga pendidikan yang diampunya, oeleh karenanya kepala sekolah harus mampu menjadi

\footnotetext{
${ }^{10}$ Ibid, 9

11 S. Wojowasito \& WJS Poerwadarminta, Kamus Lengkap Inggeris-Indonesia Indonesia Inggeris, (tt: Hasta, 1982), 198.

12 Made pidarta, Pemikiran tentang Supervise PendidikanJakarta, Bumi, Aksara, 1999), 4

${ }^{13}$ Ibid, 5
} 
supervisor bagi bawahanya atau guru yang langsung terjun menghadapi para peserta didik. ${ }^{14}$

\section{Fungsi dan peran supervisi}

Fungsi utama supervis pendidkan adalah menilai dan memperbaiki faktor-faktor yang mempengaruhi proses pembelajaran peserta didik. sedangkan Briggs mengungkapkan bahwa fungsi utama supervisi bukan hanya perbaikan pembelajaran tapi mengkoordinasi, menstimulasi, mendorong kearah pertumbuhan guru. Dengan perkataan lain seperti yang diungkapkan Kimball Wiles bahwa fungsi dasar supervise ialah memperbaiki situasi belajar mengajar dalam artian yang luas. Ada anlisis yang lebih luas seperti yang dibahas oleh Swearingen dalam bukunya supervision of instruction-fundation and dimension (1961). Ia mengemukakan 8 fungsi supervise:

1) Mengkoordinasi usaha sekolah

Oleh karena perubahan terus menerus terjadi, maka kegiatan sekolah juga makin bertambah. Usaha-usaha sekolah makin menyebar. Perlu ada koordinasi yang baik terhadap usaha sekolah. Yang dimaksud dengan usaha-usaha sekolah misalnya : usaha taiap guru, usaha-usaha sekolah, usaha-usaha bagi pertumbuhan jabatan. ${ }^{15}$

2) Memeperlengkapi kepemimpinan sekolah

Dalam masyarakat demokratis kepemimpinan yang demokratis perlu dikembangkan. Kepemimpinan itu suatu keterampilan yang harus dipelajari. Dan itu harus melalui latihan terus menerus. Dengan melatih dan melengkapi guru-guru agar mereka memiliki keterampilan dalam kepemimpinan disekolah. ${ }^{16}$

3) Memeperluas pengalaman guru-guru

Akar dari pengalaman terletak pada sifat dasar manusia. Manusia selalu mencapai kemajuan yang semaksimal mungkin. Seorang yang akan jadi pemimpin, bila ia mau belajar dari pengalaman baru ia dapat belajar untuk memperkaya dirinya dengan pengalam belajar baru. ${ }^{17}$

4) Menstimulasi usaha-usaha yang kreatif

Usaha-usaha kreatif bersumber pada pandanga tentang manusia. Semua orang percaya pada manusia diciptakan dengan memiliki potensi untuk berkembang dan berkarya. ${ }^{18}$

\footnotetext{
${ }^{14}$ Ibid, 5

${ }^{15}$ Luluk Nur Mufidah, Supervisi Pendidikan (Jogjakarta: Teras, 2009), 20

${ }^{16}$ Ibid, 21

${ }^{17}$ Ibid, 22

${ }^{18}$ Ibid, 22
} 
5) Memberi fasilitas dan penilaian yang terus menerus

Untuk meningkatkan kualitas sumberdaya diperluakan penilaian terus menerus. Melalui penelitian dapat diketahui kelemahan dan kelebihan dari hasil dan proses belajar mengajar. ${ }^{19}$

6) Menganalisis situasi belajar mengajar

Supervise diberikan dengan tujuan tertentu. Tujuannya ialah untuk memperbaiki situasi belajar mengajar. Agar usaha untuk memperbaiki situasi belajar mengajar tercapai, maka perlu analisis hasil dan proses pembelajaran.

7) Memberikan pengetahuan dan keterampilan kepada setiap anggota staf

Setiap guru memiliki potensi dan dorongan untuk berkembang, sehingga kepala sekolah harus dapat membaca serta menggali dan memanfaatkan potensi guru dan tenaga pendidik di lembaganya secara potensial dan maksimal.

8) Memberi wawasan yang lebih luas dan teritegrasi dalam merumuskan tujuan-tujuan pendidikan dan meningkatkan kemampuan mengajar guru-guru.

Untuk mencapai suatu tujuan yang lebih tinggi harus berdasarkan kepada tujuan-tujuan sbelumnya. Ada hierarki kebutuhan yang harus selaras. ${ }^{20}$

\section{Teknik supervise}

Dalam hal ini teknik supervise dibagi menjadi dua kelompok, yakni: teknik kelompok dan teknik individu.

1. Teknik kelompok

Teknik kelompok (group technique) dalam supervise pendidikan, ialah cara melaksanakan supervise terhadap kelompok orang yang disupervisi. Orang-orang yang diduga mempunyai masalah yang sama dapat dihadapi secara bersama-sama dalam situasi supervise oleh supervisor.

(a) Mengadakan pertemuan atau rapat (meeting)

Fungsi komunikasi manajemen sekolah dapat terlaksana dengan baik hanya apabila masing-masing warga sekolah mempunyai hak yang sama untuk mengemukakan pendapat, dan segala informasi yang ada dapat dengan segera kesemua warga dengan cepat, dan dengan isi yang tepat pula. Seorang kepala sekolah yang memenuhi fungsinya dengan baik, yaitu fungsi pengarahan (directing), pengkoordinasian (coordinating), dalam komunikasian (communicating), apabila dia tidak segan-segan menyelenggarakan pertemuan bersama dalam rapat dewan

${ }^{19}$ Ibid, 22

${ }^{20}$ Ibid, 24 
guru dan staf TU secara rutin. Tentu saja bearapa jangka waktu jarak antara pertemuan tergantung dari pertimbangan dan kepentingan sekolah masing-masing ${ }^{21}$

(b) Mengadakan diskusi kelompok (group discussion)

Diskusi adalah pertukaran pendapat tentang sesuatu masalah untuk dipecahkan bersama. Diskusi merupakan cara untuk mengembangkan keterampilan anggota-anggotanya dalam mengatasi kesulitan-kesulitan dengan jalan bertukar pikiran ${ }^{22}$

(c) Mengadakan penataran-penataran (in-service training)

Salah satu wadah untuk meningkatkan kemampuan guru dan staf sekolah adalah penataran. Dalam klasifikasi pendidikan, penataran dikategorikan sebagai (in-service training),senbagai jenis lain dari pre-service training, yang merupakan pendidikan sebelum yang bersangkutan diangkat jadi pegawai resmi. Peraturan semacam ini dapat dilakukan disekolah sendiri dengan mengundang narasumber, tetapi dapat diselenggarakan bersama antar bebrapa sekolah, jika diinginkan biaya yang lebih irit.

(d) Seminar

Seminar adalah bentuk belajar mengajar berkelompok dimana sejumlah kecil (10-15) orang mengadakan pendalaman atau penyidikan tersendiri bersama-sama terhadap berbagai masalah dengan dibimbing secara cermat oleh seorang atau lebih pengajaran pada waktu tertentu, kelompok ini bertemu untuk mendengarkan laporan salah seorang anggotanya maupun untuk mendiskusikan masalah-masalah yang dikumpulkan oleh anggota kelompok (Sahertia 2000:111) ${ }^{23}$

2. Teknik individual

(a) Mengadakan kunjungan kelas (Classrom Visitation)

Yang dimaksud kunjungan kelas atau classroom Visitation adalah kunjungan yang dilakukan oleh pengawas atau kepala sekolah kesebuah kelas, baik ketika kegiatan sedang berlangsung atau melihat atau mengamati guru yang sedang mengajar, ataupun ketika kelas sedang kosong, atau sedang berisi siswa tetapi guru sedang tidak mengajar. ${ }^{24}$

Teknik kunjungan kelas bila dibandingkan dengan teknik observasi Nampak sepintas seperti berbaur tidak mudah dibedakan. Ada ahli yang menyamakan kunjungan kelas dengan observasi kelas sebab cara kerja

\footnotetext{
${ }^{21}$ Suharsimi Arikunto, Prosedur Penelitian Suatu Pendekatan Praktik, (Jakarta: Rineka Cipta, 1980), 270

22 Piet A. Suhertian, Konsep dasar dan Teknik Supervisi Pendidikan, (Jakarta: Rineka Cipta, 2000), 96

23 Ibid, 111

${ }^{24}$ Suharsimi Arikunto, Prosedur Penelitian Suatu..., 55
} 
supervisor pada kedua teknik itu sama saja. Ada ahli yang mensejajarkan kedua teknik itu, mereka memandang keduanya dilakukan berurutan, yaitu berkunjung dan mengobservasi. Ada pula ahli yang membedakan teknik kunjungan kelas dengan observasi kelas, sebab cara dan tujuanya berbeda. ${ }^{25}$

(b) Mengadakan observasi kelas (classroom Observation)

Yang dimaksud observasi kelas atau classroom observartion ialah kunjungan yang dilakukan oleh supervisor, baik pengawas atau kepala sekolah kesebuah kelas dengan maksud untuk mencermati situasi atau peristiwa yang sedang berlangsung dikelas yang bersangkutan.

Salah satu cara supervisor melakukan supervise ialah dengan mengobservasi kelas yang sedang belajar dibawah bimbingan gurunya tujuanya ialah ingin memperoleh data tentang segala sesuatu yang terjadi didalam proses belajar mengajar. Data ini sebagai dasar suoervisor melakukan bimbingan terhadap guru yang diobservasi. Pembinaan memang harus dilaksanakan atas dasar kenyataan.

(c) Mengadakan wawancara perseorangan (individual interview)

Wawancara perseorangan dialakukan apabiala supervisor berpendapat bahwa dia menghendaki adanya jawaban darin individu tertentu. Hal ini dapat dilakukan pertama apabila ada masalah khusus pada individu guru dan staf sekolah lain yang penyelesaianya tidak boleh didengar oleh orang lain ke-2 apabila supervaisor ingin mengecek kebenaran data yang sudah dikumpulkan dari orang lain. Dalam hal ini wawancar perseorangan adalah teknik yang tepat agar orang yang diwawancarai tidak berpengaruh oleh pendapat orang lain. ${ }^{26}$

(d) Pertemuan formal

Pertemuan formal adalah pertemuan yang sengaja diadakan pada waktu tertentu, yang dihadiri guru-guru atau guru-guru dengan supervisornya. Pertemuan ini bisa berupa pertemuan empat mata, bisa juga pertemuan supervisor dengan sekelompok guru yang akan membahas topic yang sama. Topik yang dibahas bisa berupa hasil observasi supervisor terhadap aktivitas guru dalam kelas, dapat juga topic-topik lain yang pada waktu-waktu lampau belum dibahas atau pembahsanya belum tumtas.

(e) Pertemuan informal

Dalam setiap organisasi peretemuan foremal dengan petemuan informal sama pentingnya dalam usaha memajukan organisasi itu. Begitu pula halnya dengan organisasi pendidikan atau sekolah apa yang dibahas

\footnotetext{
${ }_{25}$ Made pidarta, Pemikiran Tentang Supervise Pendidikan (Jakarta, Bumi Aksara :1999), 227

${ }^{26}$ Luluk nur mufidah, Supervise Pendidikan (Jogjakarta, teras :2009),89
} 
dalam pertemuan informal memberi sumbangan yang sama besarnya dengan apa yang dibahas dalam peretemuan formal.

(f) Rapat guru

Rapat guru dibedakan dengan pertemuan formal ialah karena dalam rapat ini semua guru ikut terliubat, sedangkan dalam pertemuan formal belum tentu, walaupun menurut sifatnya rapat guru juga termasuk pertemuan formal. Biasanya rapat guru ini diadakan secara berkala tiga bulan sekali atau enam bulan sekali menurut kebutuhan. Masalah yang dibahas pada umumnya mencakup semua aktifitas sekolah. Namun demikian amant sering masalah yang dibahsas menyangkut proses belajar mengajar, bila hal ini terjadi, sebenarnya rapat guru ini tidak lain dari pada supervise. ${ }^{27}$

\section{Tipe-tipe supervise}

Supervisi memiliki beberapa tipe, tipe-tipe tersebut adalah:

1) Tipe inspeksi

Supervisi dengan tipe inspeksi ini biasanya terjadi dalam administrasi dan model kepemimpinan yang otokratis Supervisi tipe inspeksi ini dikonotasikan sebagai upaya untuk mencari-cari kesalahan.

2) Tipe Laisses Faire

Supervisi ini berbeda dengan tipe inspeksi. Kalau dalam inspeksi bawahan diawasi secara ketat dan harus menurut perintah atasan, pada tipe laisses faire para pegawai dibiarkan saja bekerja sekehendak hatinya. Sebagai contoh guru boleh mengajar sebagaimana yang mereka inginkan, baik dalam pengembangan materi maupun dalam pemilihan metode dan alat pembelajaran (Arikunto, 2004: 15).

3) Tipe Coersive

Tipe koersif ini juga sering disebut dengan istilah supervise otoriter. Supervisi tipe ini tidak jauh berbeda dengan tipe inspeksi. Tipe supervisi ini bersifat memaksa. Tipe supervisi ini tepat jika diterapkan pada hal-hal awal. Misalkan saja untuk guru yang baru belajar mengajar.

4) Tipe Training and Guidance

Supervisi tipe ini diartikan sebagai memberikan latihan dan bimbingan. Sesuai dengan makna luas pendidikan yakni merupakan proses pertumbuhan, perkembangan, serta peningkatan, maka supervisi mendorong terjadinya pertumbuhan. Untuk itu diperlukan tambahan latihan dan bimbingan kepada guru dan staf tata usaha.

5) Tipe Demokratis

Supervisi tipe demokratis memerlukan kondisi dan situasi khusus. Tentu saja adanya kepemimpinan yang bersifat demokratis pula. Hal

${ }^{27}$ Luluk Nur Mufidah, Supervisi Pendidikan......., 91 
yang perlu diperhatikan pada supervisi tipe ini adalah bahwa pemimpin bukan hanya memusatkan perhatiannya pada kemajuan situasi belajar mengajar saja. Untuk meningkatkan kualitas pembelajaran, kepala sekolah sebagai siupervisor harus mampu meningkatkan kepemimpinan yang dapat mengembangkan program sekolah dan memberdayakan lingkungan bagi semua guru, mengusahakan kelengkapan sarana prasarana belajar mengajar dan berkomunikasi secara optimal dalam pencapaian tjuan dan cara melaksanakan strategi pencapaiannya. ${ }^{28}$

\section{Faktor yang mempengaruhi berhasil tidaknya supervisi}

Menurut Purwanto (2004: 118), ada beberapa faktor yang mempengaruhi berhasil tidaknya supervisi atau cepat lambatnya hasil supervisi, antara lain:

1) Lingkungan masyarakat tempat sekolah itu berada

2) Besar kecilnya sekolahyang menjadi tanggung jawab kepala sekolah

3) Tingkatan dan jenis sekolah

4) Keadaan para guru dan pegawai yang tersedia

5) Kecakapan dan keahlian kepala sekolah itu sendiri.

Diantara faktor-faktor tersebut faktor kecakapan dan keahlian kepala sekolah itu sendiri adalah yang terpenting. Bagaimanapun baiknya situasi dan kondisi yang tersedia, jika kepala sekolah itu sendiri tidak mempunyai kecakapan dan keahlian yang diperlukan, semuanya tidak akan ada artinya. Sebaliknya, adanya keahlian dan kecakapan yang dimiliki oleh kepala sekolah, segala kekurangan yang ada akan menjadi perangsang yang mendorong untuk selalu berusaha memperbaiki dan menyempurnakannya.

a) Fungsi kepala sekolah sebagai supervisor

Kegiatan atau usaha-usaha yang dilakukan oleh kepala sekolah sebagaimana fungsinya sebagai seorang supervisor menurut Purwanto (2004: 119) antara lain:

1) Membangkitkan dan merangsang para guru dan pegawai sekolah didalam menjalankan tugasnya masing-masing dengan sebaik-baiknya.

2) Berusaha mengadakan dan melengkapi alat-alat perlengkapan sekolah termasuk media instruksional yang diperlukan bagi kelancaran dan keberhasilan proses belajar mengajar.

\footnotetext{
28 https://www.jurnal.pendidikan.seach.Jurnal Joko widodo, Supervisi Guru Mata Pelajaran Ekonomi di Indonesia (jurnal :08/04/2018, 21:22)
} 
3) Bersama para guru berusaha mengembangkan, mencari dan menggunakan metode-metode mengajar yang lebih sesuai dengan tuntutan kurikulum yang sedang berlaku.

4) Membina kerjasama yang baik dan harmonis diantara para guru dan pegawai lainnya.

5) Berusaha mempertinggi mutu dan pengetahuan para guru dan pegawai sekolah, antar lain dengan mengadakan diskusi kelompok, menyediakan perpustakaan sekolah dan atau mengirim mereka untuk mengikuti penataran-penataran, seminar sesuai dengan bidangnya masing-masing.

6) Membina hubungan kerjasama antara sekolah, komite sekolah dalam rangka peningkatan mutu pendidikan para siswa. ${ }^{29}$

\section{Penutup}

Supervisi kepala sekolah dalam meningkatkan kinerja guru sangatlah harus diperhatikan dan dilaksanakan baik mulai dari awal perencanaan pembelajaran hingga sampai evaluasi pembelajaran setiap tahun ajaran baru, kepala sekolah melaksanakan tuganya sebagai supervisor dengan menilai, membimbing, dan mengontrol para bawahanya di mulai darai awal perencanaan pemebelajaran yanag dimulai dari pembuatan RPP (Rencana Pelaksanaan Pembelajaran) hingga samapai evaluasi pembelajaran yanag mana secara mutlak itu meruapakan tugas apara bawahanya yang harus di awasi agar tugas dan kinerja guru dapat sesuai ketercapaian yang telah ditentukan Memulai pengawasanya dari kinerja guru. Dan tugas kepala sekolah adalah mengawasi, menilai, dan mengontrol para bawahanya. Dengan danya supervisi yanag dilakukan kepala sekolah sebagai supervisor sangatlah berdampak atau berpengaruh terhadap peningkatan kinerja guru yan ada di sekolah ini, dengan adanya supervisi maka para guru akan merasa diperhatikan, diawasi, serta di control dalam kinerjanya sehingga para guru dapat berpacu atau semangat dalam menjalankan pekerjaanya.

\footnotetext{
${ }^{29} \mathrm{https} /$ /www.google.co.id/seach,jurnal. cendikiawan. Edi Supriono, Pengaruh Supervisi Kepala Sekolah Terhadap Kinerja guru. 14/02/2018, 8:45
} 


\section{Daftar Pustaka}

Arikunto, Suharsimi. 1980., Prosedur Penelitian Suatu Pendekatan Praktik, Jakarta: Rineka Cipta,

https//www.google.co.id/seach,jurnal. cendikiawan. Edi Supriono, Pengarub Supervisi Kepala Sekolab Terhadap Kinerja guru. 14/02/2018, $8: 45$

https://www.jurnal.pendidikan.seach.Jurnal Joko widodo, Supervisi Guru Mata Pelajaran Ekonomi di Indonesia (jurnal :08/04/2018, 21:22)

Marno. 2013. Manajemen dan Kepemimpinan Pneidikan Islam, Bandung: PT. Rafika, Aditama.

Mufidah, Luluk Nur. 2009. Supervisi Pendidikan, Jogjakarta, Teras.

Pidarta, Made. 1999. Pemikiran tentang Supervise Pendidikan Jakarta, Bumi, Aksara.

Suhertian, Piet A. 2000., Konsep dasar dan Teknik Supervisi Pendidikan, Jakarta: Rineka Cipta,

Wahyudi. 2012. Kepemimpina Kepala Sekolah Dalam Organisasi Pembelajaran, Bandung, Al Fabeta.

Wojowasito S. \& WJS Poerwadarminta, 1982. Kamus Lengkap InggerisIndonesia Indonesia Inggeris, tt: Hasta 